\title{
Quinoa (Chenopodium quinoa Willd.) and its relationship with agroclimatic characteristics: A Colombian perspective
}

\author{
Miguel García-Parra ${ }^{1 *}$, Andrés Zurita-Silva ${ }^{2}$, Roman Stechauner-Rohringer $^{1}$, Diego Roa-Acosta ${ }^{1}$, \\ and Sven-Erik Jacobsen ${ }^{3}$
}

${ }^{1}$ Universidad del Cauca, Facultad de Ciencias Agrarias, 190003 Popayán, Cauca, Colombia.

"Corresponding author (miguelgarciap@unicauca.edu.co).

${ }^{2}$ Instituto de Investigaciones Agropecuarias, INIA Intihuasi, Colina San Joaquín s/n, 1722093 La Serena, Chile.

${ }^{3}$ Copenhagen University, Quinoa Quality ApS, Regstrup, Rederiksberg, Denmark.

Received: 23 October 2019; Accepted: 16 January 2020; doi:10.4067/S0718-58392020000200290

\begin{abstract}
A diversity of crops of agri-food interest are produced in the Colombian highlands, including quinoa (Chenopodium quinoa Willd.), an annual herbaceous plant with white, yellow, red or black seeds, containing between $12 \%$ and $21 \%$ protein. It is an important source of lysine and methionine. Historically, this plant has played a fundamental role in human nutrition, due to its multiple benefits for disease prevention and treatment. Salinity is the abiotic stress most studied in quinoa; however, the development of this crop on all continents has led to the study of other factors, such as cold and heat, resulted by the increase in weather patterns. This review describes the progress in the temperature effects, photoperiod, atmospheric $\mathrm{CO}_{2}$ concentration and agronomic aspects on the growth and development of quinoa, as well as compositional characteristics of the seeds and their prospective related to the agroclimatic diversity of Colombia.
\end{abstract}

Key words: Agro-industrial seed, climatic diversity, eco-physiology.

\section{INTRODUCTION}

Quinoa (Chenopodium quinoa Willd.) belongs to the family Amaranthaceae and is mainly grown in the Altiplano and arid areas of Andean region of South America although is currently cultivated on all continents, it also displays wide adaptability to altitudes ranging from 0 to $4000 \mathrm{~m}$, i.e. cold, temperate and warm environments (Del Castillo et al., 2008; Bazile et al., 2014). A significant increase of the cropped area has been recorded during the recent years (2000-2019), mainly in Bolivia with increments from 35690 to $64789 \mathrm{ha}^{-1}$ and Peru with 27578 to $37625 \mathrm{ha}^{-1}$. The principal importing countries of their harvests are USA (53\%), Canada (15\%), France (8\%), Netherlands (4\%), Germany (4\%), Australia (3\%) and UK (2\%) (FAO-ALADI, 2014; Jaikishun et al., 2019).

During recent decades, plant growth and development has increasingly been studied due to the incidence of climatic modifications, such as climate change that alters both natural environments and as a consequence on agricultural production that might be of pivotal relevance (Korres et al., 2016). This has led to eco-physiological research evaluating environmental consequences in addition to the interaction between physical and biotic factors altering plant physiology. Thus, identifying adaptive and crop tolerance capacity is of the utmost importance (Jarma et al., 2012; Fischer et al., 2016). Indeed, quinoa exhibit multiple abilities to stand solar radiation, temperature, water availability and atmospheric $\mathrm{CO}_{2}$ concentration, allowing its cultivation on different agroecological zones (Zurita-Silva et al., 2014; Melo, 2016; Reguera et al., 2018). However, agronomic aspects such as productivity and tolerance to biotic issues such as pests, diseases and weeds, become determining aspects in the agroecosystems (Hinojosa et al., 2018). 
The wide natural variability of quinoa in traits such as inflorescence type, seed color and size, production cycle duration, drought and salinity tolerance, along with grain nutritional value, have allowed quinoa cultivation to become one of main strategies to cope with climate change effects, and simultaneously an alternative for food security in different regions of the world (FAO-ALADI, 2014; Bazile et al., 2016; Präger et al., 2018). However, in addition to genetic traits that encode for phenological, morphological, physiological and metabolic attributes of quinoa, it has been relevant to determine the impacts of abiotic factors that are determinants of the grain composition and its aptitude for utilization in food industry.

Given that quinoa reference genome has been published (Jarvis et al., 2017), some countries have potential interest for its cultivation and research increased significantly during recent years, a positive boost in quinoa surface is expected to become relevant all over the world in the next future. There are currently over thousand publications highlighting effects of climatic variation on quinoa production. Those studies have mainly focused on diversity, phenology, physiology, productivity and agri-food characteristics of its seeds. The countries enhancing scientific dissemination through articles include USA, UK, Italy, Germany and France, whereas in South America the highest contributions in studying this crop are coming from Chile, Argentina and Brazil (Figure 1) (Ruiz et al., 2014; Bazile et al., 2016; García-Parra and PlazasLeguizamón, 2019).

In the case of Colombia, there are two predominant cultivated varieties, Blanca de Jerico and Tunkahuan, which usually have a yield between 1 and $2 \mathrm{t} \mathrm{ha}^{-1}$ (MADR, 2018). The statistics generate concerns for professionals, academics and producers, given the productive gap compared to Bolivia and Peru. Similarly, agroindustry potential is threatening by low protein and fat content of quinoa materials that exist in central region of the country (Garcia-Parra et al., 2018). For this reason, different governmental and private agencies are currently carrying out ex situ research, which aim is the evaluation of cultivars and varieties from other countries (Torres et al., 2000; Delgado et al., 2009), in order to generate competitiveness in properties such as precocity and productivity.

The influence of the Andes range over edaphoclimatic diversity has also an impact on biological behavior of crops and therefore on compositional characteristics of its kernels, potentially conferring them special nutritional value. Due this high biogeographic diversity the knowledge and evaluations of eco-physiological and compositional aspects of seeds, is still not comprehensive. This work aims to review recent advances and to explore relationship of climatic factors and agronomic aspects of quinoa production with emphasis in Colombia, and to compare with those obtained under similar and different agroecosystems in other countries.

Figure 1. Countries with the highest number of quinoa publications according to the Scopus database.

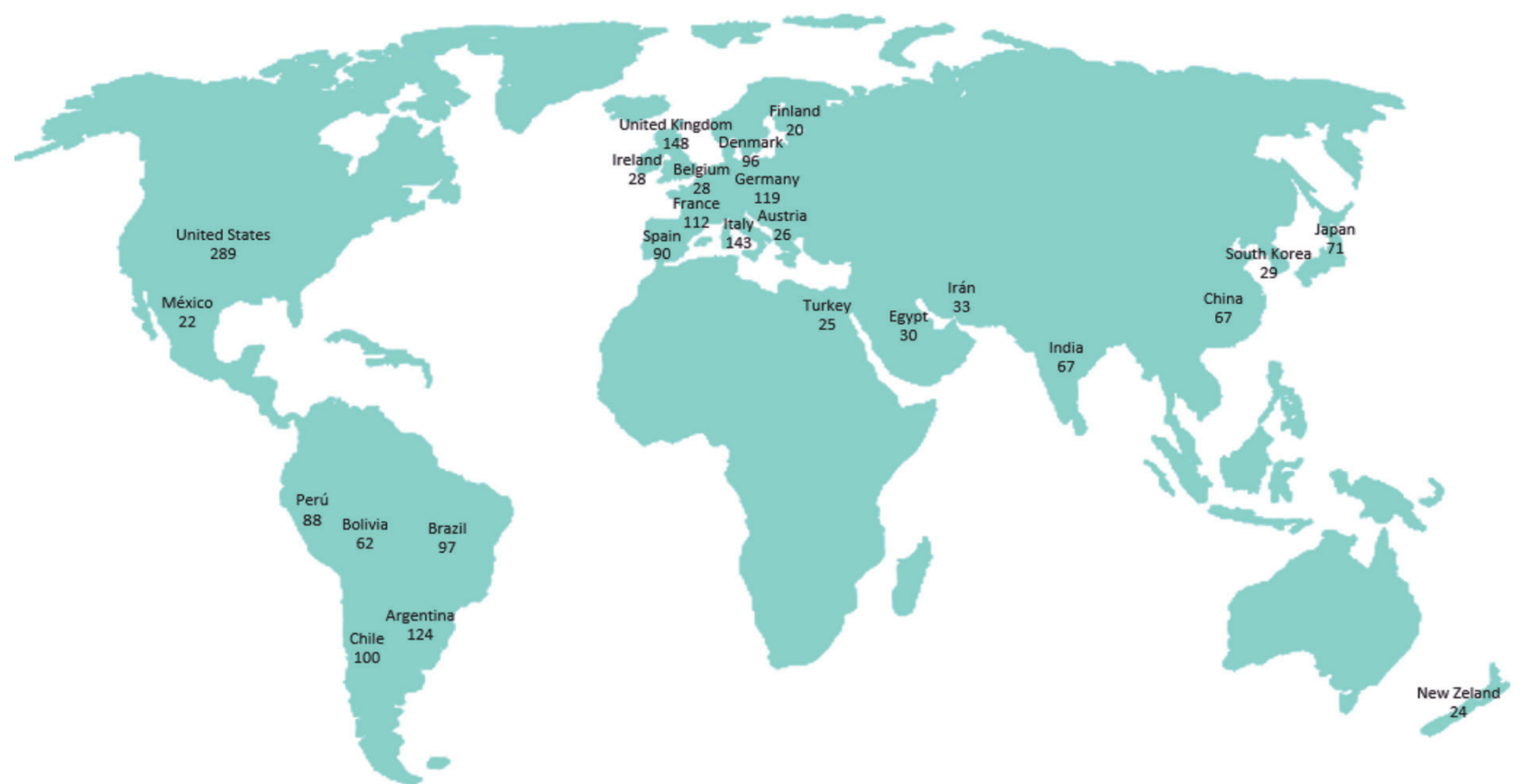

Source: All authors. 


\section{Distribution of quinoa cultivation}

For centuries, quinoa has been the main food source for different populations of the Andean region, mainly in latitudes from $11^{\circ} \mathrm{N}$ in Colombia to $40^{\circ} \mathrm{S}$ in Chile. Currently, this crop is expanding to other continents, owing to its adaptability to adverse agroclimatic conditions, as well as to its ability to exhibit compositional characteristics of relevance in the food industry (Jacobsen, 2017). Indeed, this crop has gained significance in Europe, North America, Asia and Africa, where many countries joined the "Quinoa: a multipurpose crop for agricultural diversification of the European Counties" project, launched in 1993, which was based on the nutritional potential of its seeds and the promising high quality forage (Murphy and Matanguihan, 2015).

Historically, a large part of the Colombian Andean region, i.e. in the current Boyacá and Cundinamarca departments, quinoa was the basis of food and culture of various indigenous communities including the Muiscas (Figure 2, green arrows) (Guerrero-López, 2018). Through cultural activities and trade it was transferred to different parts of the country. The Nariño department is the Colombian origin center of this species, which was later cultivated in the Valle del Cauca, Quindío and Cauca (Figure 2, red arrows). The latter is currently the region with highest production of this crop (MADR, 2016; 2018).

\section{Quinoa description}

Quinoa is a gynomonoecious and dicotyledonous plant that exhibits herbaceous behavior and annual cycle. It develops a main stem with lateral branches, which hold alternate leaves showing different colors as expression of anthocyanin and carotenes presence. This plant exhibits sound growth in Colombia, with a diversity of cultivars reaching up to $2.3 \mathrm{~m}$ height (Torres et al., 2000; Montes-Rojas et al., 2018). The root system is pivotal, with presence of secondary roots distributed in densities depending on soil conditions, occasionally penetrating up to $1.5 \mathrm{~m}$ depth where water requirements are met (Bosque Sanchez et al., 2003; Alvarez-Flores et al., 2014).

The quinoa inflorescence is a panicle, between 15 and $100 \mathrm{~cm}$ in length that grows at the terminal plant apex, either on main stem or at lateral branches. From a central axis develops several secondary branches on this structure, conforming compact, lax or mixed inflorescences, bearing hermaphrodite or unisexual flowers (Abdelbar, 2018); consequently, hermaphrodite flowers are located at the distal end of main, secondary and tertiary branches of the inflorescence (Olvera et al., 2008).

Figure 2. Origin and development dynamics of quinoa in Colombia.

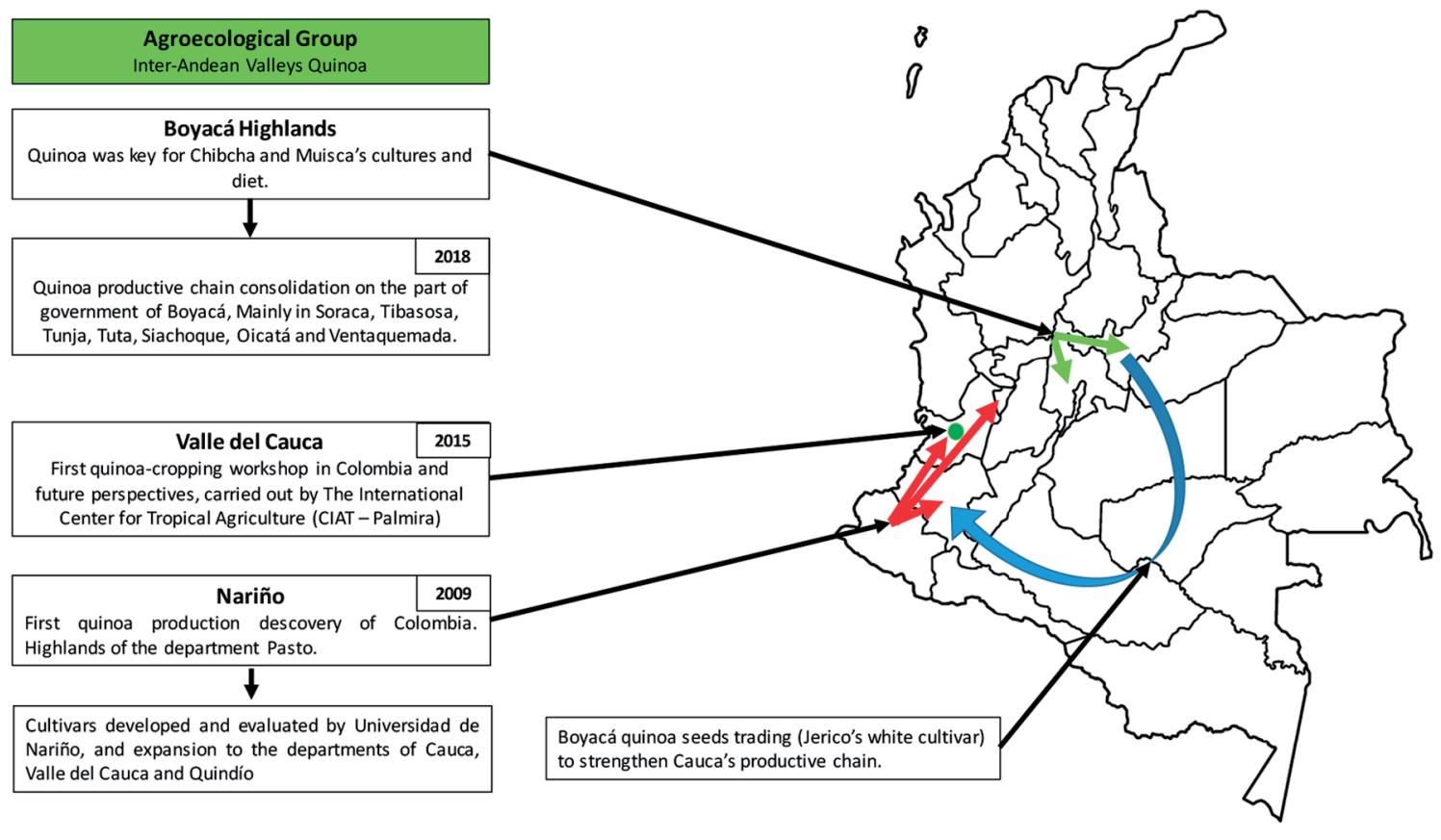

Source: All authors. 
The seed is recognized as an achene with lenticular, ellipsoidal, conical or spherical morphology that varies according to genetic traits. In Colombia, existing cultivars derived from mixture of different genotypes due to the absence of commercial cultivars, giving rise to sowing with seeds originating from the exchange between farmers, expressing different shapes, colors and sizes, displaying high intravarietal heterogeneity in a same planting field. In example genotypes CV1 and CV2 present high saponins and tannin contents, foam accumulation and dark coloration that are associated with a greater presence of saponins and tannins respectively, whereas CV3 and CV4 present lower saponins and tannin contents (Figure 3). Thus, aspects such as germination speed, seed viability and presence of secondary metabolites, saponins, tannins and phytic acid are very variable and not fully characterized, even considering the whole diversity of 16422 accessions worldwide (Jäger, 2015; Veloza-Ramírez et al., 2016).

\section{Climate variability and quinoa physiology}

Climate oscillations are among main drivers that determine plant distribution, either directly, through physiological limitations imposed to plant development, or indirectly, as a consequence of competition factors for resources (Kosanic et al., 2018). Marengo et al. (2014) estimate that global average temperatures will rise between 1 and $3.7^{\circ} \mathrm{C}$ by the end of this century, meaning that daily minimum temperatures could rise faster than daily maximum temperatures, resulting in significant impacts on crop production in the region. Accordingly, species with food potentiality are needed, which not only possess adaptability to and tolerate unexpected climate changes, but also manifest desirable nutritional features as compositional characteristics of protein, fat, fiber and carbohydrates superior to cereals (Bazile et al., 2014). These considerations are indeed concerns over several research lines conducted in quinoa. Nevertheless, despite species of the Amaranthaceae family adapt themselves to adverse climatic factors, interesting advantages emerge in quinoa (Murphy and Matanguihan, 2015; Korres et al., 2016), since is a C3 photosynthetic pathway species. Thus, change rate of carboxylase or oxygenase activity of the RuBisCO is more receptive to environmental factors, as a result of the anatomical structure where the $\mathrm{CO}_{2}$ fixation occurs. Therefore, variable factors such as temperature, radiation, water availability and quinoa genotype itself, generally determine a higher ability to tolerate and adapt to agroclimatic conditions of crop site (Del Castillo et al., 2008).

Considering that environmental factors jointly determine fitness and expression of plant productivity, it is fundamental to consider a multidisciplinary approach to study ecophysiological quinoa performance. Nevertheless, most studies have focused on individual effects of climatic variables, although different meteorological sources predict higher frequency of extreme events, especially in the Andean region (Ruiz et al., 2014). Additionally, understanding the response mechanisms of different cultivars under different soil and varying climatic conditions becomes essential for assessing suitable varieties that finally may express higher yields as well as compositional seed attributes.

Figure 3. Predominant cultivars of the central area of Colombia with different saponins and tannins contents.

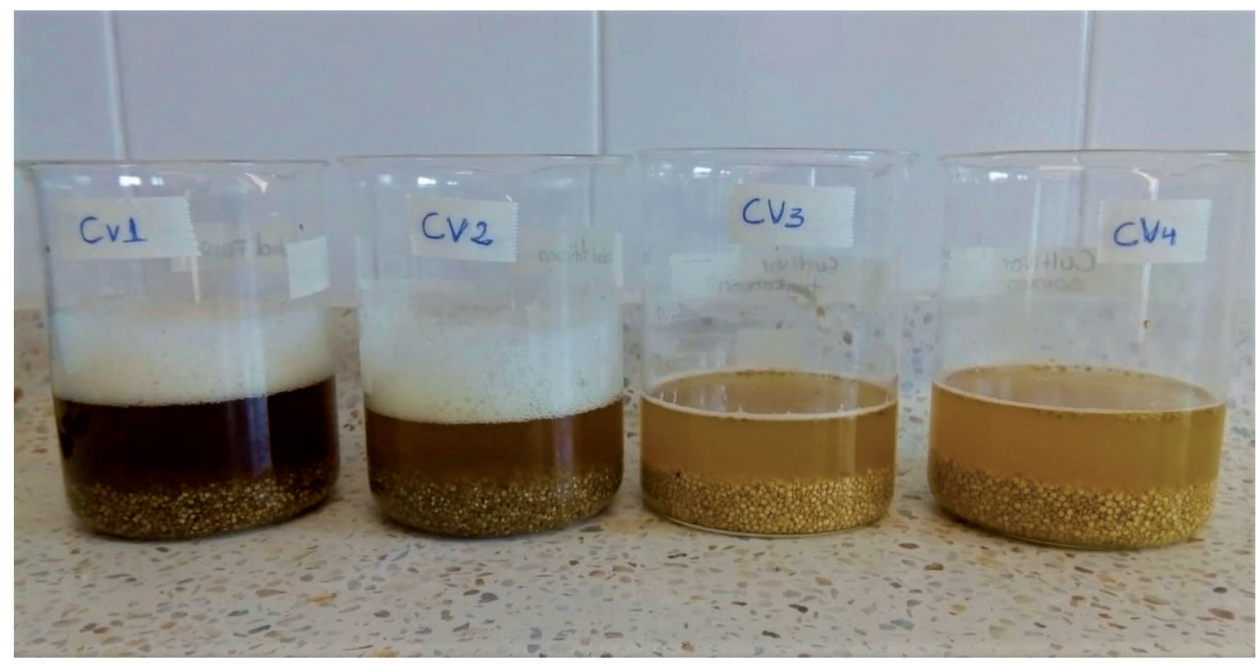

Source: All authors. 


\section{Effect of temperature on quinoa}

Temperature is one of the most important climatic factor defining quinoa's development, as the species responds to a varying threshold temperature depending on the production site (Bertero, 2003), where thermal requirements, namely temperature sum should be known. The physiological base temperature $\left(T_{b}\right)$, also called zero vegetation is temperature below which process of interest does not progress. The $T_{b}$ varies between cultivars and possibly varies with growth stage. According to Bois et al. (2006) the concept thermal development was used to analyze results in growth experiments for different crops, integrating the degree days required for a given phenological phase, calculating $T_{b}$ based on minimal standard deviation and utilized with variable number of experiments, overall mean temperature and number of days to accomplish a given phase during the $\mathrm{i}^{\text {th }}$ experiment. In quinoa, $\mathrm{T}_{\mathrm{b}}$ is $1{ }^{\circ} \mathrm{C}$ for cultivars from Bolivia and Colombia (Bertero, 2001). However, this may also vary depending on the cultivar phenological stage. For example, $\mathrm{T}_{\mathrm{b}}$ for germination in highlands cultivars is $1^{\circ} \mathrm{C}$ as studied by Mamedi et al. (2017), whereas for Jacobsen and Bach (1998) it is $3{ }^{\circ} \mathrm{C}$ for coastal/lowland cultivars. Consequently, during the vegetative cycle $\mathrm{T}_{\mathrm{b}}$ should increase to $6{ }^{\circ} \mathrm{C}$ and in flowering stage it should be around $3{ }^{\circ} \mathrm{C}$ (Bertero, 2003), whereas for inter-Andean valley quinoa $\mathrm{T}_{\mathrm{b}}$ should be $1{ }^{\circ} \mathrm{C}$, regardless of developmental stage (Jacobsen et al., 2005). This ecotype component might explain the strong variation in temperature responses to heat stress, which is triggered by increase in temperature beyond threshold tolerance, affecting plant growth and development. In Colombia, main quinoa production areas exhibit temperatures between 10 and $15{ }^{\circ} \mathrm{C}$ (García and Plazas, 2018), regarded as optimal ranges for cultivation. Nonetheless, during recent years, sudden temperature changes on highlands of Cundinamarca and Boyacá departments as well as the Andean region of Nariño department have led to wide oscillations between hot and cold days (up to $20^{\circ} \mathrm{C}$; Melo, 2016). According to Sanabria and Lazo (2018) this generates a decrease in growth and development of some quinoa cultivars, mainly resulting from photosynthesis inhibition, cell membrane denaturation, or even plant tissue senescence and necrosis.

Regarding high temperatures, their effects on physiological behavior has also been studied. Yang et al. (2016) reported significant variations in photosynthesis, stomatal conductance, fluorescence and chlorophyll content at temperatures between 20 and $25^{\circ} \mathrm{C}$; also Becker et al. (2017) found induced phenological changes, predominantly in terms of branch elongation and stomatal density modification in 'Achachino', where temperatures ranged from 20 to $25.5^{\circ} \mathrm{C}$. Similar results were observed on morphological behavior of 29 quinoa cultivars from five ecotype groups (Bhargava et al., 2007), whereas temperature influenced leaves number, plant height and changes on phenological stages duration for most important cultivar of central Colombia (García et al., 2017).

\section{Nocturnal temperatures}

The equatorial location of Colombia and effects of different altitudes influence remarkable variations in temperature, which can be considered much more relevant than in extratropical areas. Indeed, extreme temperature fluctuations in association with frosts, determine part of physiological, phenological and productive behavior of quinoa in productive regions (Bois et al., 2006; Murphy and Matanguihan, 2015). According to Jacobsen et al. (2005), low nocturnal temperatures limit photosynthetic activity of the next day. Hence, cultivars from highlands agroecological conditions express greater tolerance to low nocturnal temperatures $\left(-8{ }^{\circ} \mathrm{C}\right)$ compared to quinoa from inter-Andean valleys $\left(-4^{\circ} \mathrm{C}\right)$.

As a consequence of the rise of nocturnal temperatures in South America, remarkable changes of plant behavior have been observed, particularly in terms of reduction of phenological stages (early cultivars) and their yield, as it has also been the case of some cereals and legumes. In quinoa, Lesjak and Calderini (2017) found that increment of nocturnal temperatures at flowering stage negatively affected biomass production, size and number of grains in a range of $23 \%$ to $31 \%$. According to Bunce (2017), intraspecific variation responses in combination of high nocturnal temperatures $\left(14^{\circ} \mathrm{C}\right)$ with different $\mathrm{CO}_{2}$ concentrations during anthesis stage led to an increase in seed yield.

\section{Photoperiod}

Quinoa is a species that experienced a notable distribution on all continents during last years, being grown in regions of different latitudes, where shift of short and long days is constant during certain year's season. However, this crop is photoperiod-sensitive throughout its developmental stages, particularly at reproductive stage (Bertero et al., 1999b; Christiansen et al., 2010). The most relevant effects of a long photoperiod are expressed after flowering stage, resulting in a continuous development of vegetative stage and a delay in grain filling induction, growth and maturation stages (Murphy and Matanguihan, 2015). 
Previous results evidence that $C$. quinoa is a crop that undergoes phenological stage development in proportional times during short days, so it is considered an facultative short-day plant (Bendevis et al., 2014; Singh, 2019) and according to Bertero et al. (1999a), cultivars from Colombia, Ecuador, Peru, Bolivia and Chile exposed to 10.25, 12, 14 and 16 light hours, exhibit quantitative changes at vegetative stage under short days influence, depicting a negative correlation with origin latitude of the respective cultivars. However, it is emphasized that 'Nariño' (Colombia) has a critical photoperiod at $13.3 \mathrm{~h}$, whilst on Chilean and Peruvian cultivars susceptibility to longer photoperiods (14.3-14.5 h) is lower.

\section{$\mathrm{CO}_{2}$ Concentration}

Currently, there are profuse experimental evidences evaluating variations in exchange of $\mathrm{O}_{2}, \mathrm{CO}_{2}$, and water on foliage, as well as their influence on plant performance in response to climate oscillations (Korres et al., 2016). Many of these studies have evaluated Amaranthaceae species. For instance, Tsutsumi et al. (2017) found that photosynthetic rate is affected by gas exchange and affects stomatal conductance in $\mathrm{C} 4$ species. Similarly, for $C$. quinoa, research has demonstrated a C3 photosynthetic route, which according to $\mathrm{CO}_{2}$ fixation phase through Kalvin cycle, morphological structure and development of metabolic pathway in mesophyll cells, strongly respond to $\mathrm{CO}_{2}$ saturation as compared to $\mathrm{C} 4$ plants, revealing a close relationship with $\mathrm{CO}_{2}$ concentration of surrounding environment (Figure 4) (Taiz and Zeiger, 2006), thus resulting in the increase of dry mass of stems, shoots, seeds as well as harvest index, but strongly dependent of cultivar (Bunce, 2017).

During photosynthesis process, quinoa shows a higher point of gas compensation compared to that of $\mathrm{C} 4$ plants, evidencing a positive response to increase in intercellular $\mathrm{CO}_{2}$ concentration (Murphy and Matanguihan, 2015), and its positive association with hydric and nutritional status of quinoa plants, which in turn depends on agronomic practices (Bascuñán-Godoy et al., 2018b). For these reasons, results are not only attributed to the increment of $\mathrm{CO}_{2}$ concentration, but also in interactions with temperature, light, water and nutrients. According to Geissler et al. (2015), an increase in photosynthetic efficiency of quinoa leads to a greater tolerance to edaphic salinity, improving stomatal activity and reducing potential oxidative stress, that is, risk of electron transport breakdown. Similar results were obtained by González et al. (2011), who reported that among 10 cultivars those showing higher photosynthesis and conductances were also generally more productive when facing drought conditions.

Changes in compensation points of different quinoa cultivars are the output of management practices such as organic fertilization, which improves amount of $\mathrm{CO}_{2}$ incorporated per unit of water extracted, also reflected in the reduction of stomatal conductance (Villalobos-Rodríguez, 2001). The comparison of some photosynthetic parameters on different quinoa cultivars are shown in Table 1. Genotypic variation among cultivars such as Hualhuas, CICA, Faro, UdeC9 and BO78, exhibit significant differences in physiological performance: saturation and compensation points are reported (20.79-110.00 and 756.81-1525.10 $\mu \mathrm{mol} \mathrm{m}^{-2} \mathrm{~s}^{-1}$ respectively), revealing a response to the balance between the $\mathrm{CO}_{2}$ captured during photosynthesis and $\mathrm{CO}_{2}$ liberation resulting from photorespiration (Taiz and Zeiger, 2006).

Figure 4. Response of quinoa $\mathrm{CO}_{2}$ assimilation to $\mathrm{CO}_{2}$ concentration increase.

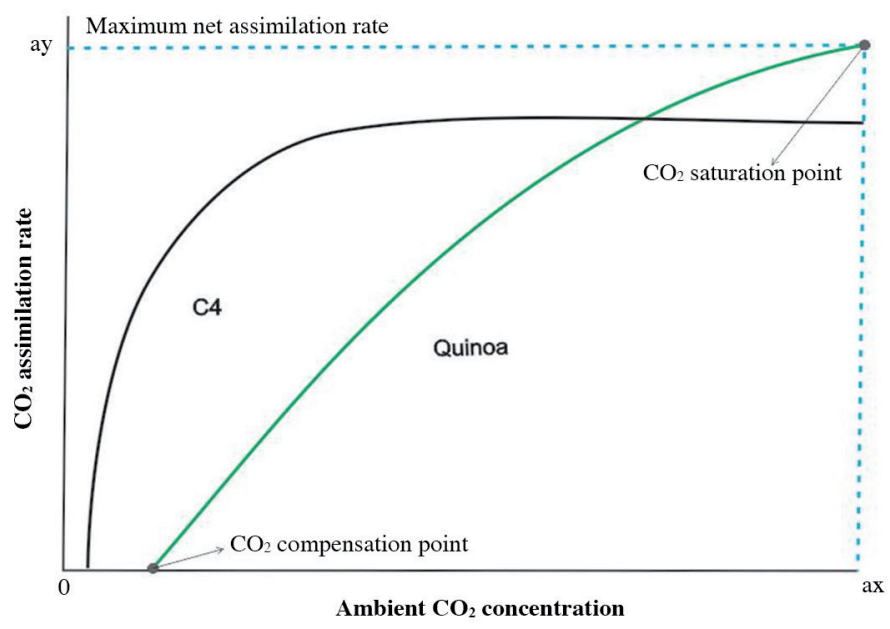

Adapted from Taiz and Zeiger (2006), Bascuñán-Godoy et al. (2018b), Huarancca Reyes et al. (2018). 
Table 1. Photosynthetic parameters of different quinoa cultivars.

\begin{tabular}{|c|c|c|c|c|}
\hline Cultivar & $\begin{array}{c}\text { Compensation } \\
\text { point }\end{array}$ & $\begin{array}{l}\text { Saturation } \\
\text { point }\end{array}$ & $\begin{array}{c}\text { Stomatal } \\
\text { conductance }\end{array}$ & Source \\
\hline & & $-\mu \mathrm{mol} \mathrm{m} \mathrm{m}^{-2} \mathrm{~s}^{-1}$ & 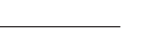 & \\
\hline Hualhuas & 20.79 & 56.81 & - & Geissler et al., 2015 \\
\hline CICA & 49.94 & 79.29 & 0.16 & Murphy and Matanguihan, 2015 \\
\hline Hualhuas & 28.40 & 49.43 & - & Eisa et al., 2012 \\
\hline Faro (h-1) & $69-85$ & - & 0.20 & Bascuñán-Godoy et al., 2018b \\
\hline UdeC9 (h-1) & $79-85$ & - & 0.30 & \\
\hline BO78 (h-1) & $71-110$ & - & 0.20 & \\
\hline CICA (Hd-Ld) & $52.34-54.03$ & 1034.94 to 1525.10 & 0.18 & González et al., 2018b \\
\hline
\end{tabular}

\section{Field grown and quinoa nutrition}

The ability of quinoa to perform on marginal soils has been assessed focusing on performance at different soil types (Becker et al., 2017). Nevertheless, crops are frequently established using seeds obtained from previous crops resulting in low production yields, and commercialization of certified seeds does not ensure real access to quality elite materials in Colombia. Sowing is performed in rows by mechanical sowing or seedlings transplant or even by hand sowing, depending on use purpose. First alternative is preferred for seed production, given that it facilitates agronomic work, with row spacing from 25 to $50 \mathrm{~cm}$ depending on cultivar (Bhargava et al., 2006). Crop responds well to $\mathrm{N}$ fertilizers applications, since it favors photosynthesis and consequently production of photoassimilates (Bascuñán-Godoy et al., 2018a). However, applications exceeding $150 \mathrm{~kg} \mathrm{ha}^{-1}$ reduce grain production, and extend the development of stems and leaves leading to increments in biomass production (Geren, 2015). Despite that, high $\mathrm{N}$ concentrations could improve the adaptability of quinoa to soils with low water availability (Bascuñán-Godoy et al., 2018b).

Considering nutrient sources, organic fertilizers at sowing is a common practice in central regions of Colombia, achieving regular production levels. García et al. (2017) reported that management of organic-mineral fertilization improve production of fresh and DM, as well as chlorophyll contents and grain yield on highlands of Cundinamarca and Boyacá departments. Conversely, Guerrero-López (2018) reported that best results in grain production $\left(2.54 \mathrm{t} \mathrm{ha}^{-1}\right)$ were achieved with synthetic fertilizer use preceded by application of chicken manure $\left(2.42 \mathrm{t} \mathrm{ha}^{-1}\right)$, displaying enhancements in physical, chemical and biological soil conditions at southern Andean Colombia.

Phosphorus is known for being an essential nutrient for plant growth and development as well as fundamental for metabolic processes, such as energy production (ATP, ADP, NADP, NADPH), an essential constituent of DNA, triose phosphate, and structural membrane component as phospholipids (Taiz and Zeiger, 2006). Its deficiency in quinoa plants causes a significant impact on plant height, delayed processes at flowering stage resulting in small inflorescences, and even malformed and smaller grains (Gómez and Aguilar, 2016). Similarly, although not functionally structural in plants, K suits fundamental roles such as osmoregulation and as cofactor of multiple enzymes. Specifically in quinoa, this macronutrient has allowed its adaption to marginal agroclimatic conditions, because its role as compatible osmolyte in stomatal guard cells and in cell vacuoles, contributing to osmotic regulation together with proline and chlorine (Hariadi et al., 2011). Andean tropical soils are characterized by excess of $\mathrm{K}$, therefore it represents an advantage for this crop.

Quinoa displays tolerance to low water availability (Morales et al., 2017), despite that processes such as germination and physiological development are directly related to water availability (Yang et al., 2016). Another environmental constraint that has attracted great interest in recent years is salinity tolerance (Table 2), given that their effects are linked to osmotic stress, i.e. reduction of water potential, and ionic stress in this crop (Ruiz et al., 2016). It has been determined that quinoa plants show positive and negative behaviors in response to increments in soil salt concentrations. For this reason it is considered a facultative halophyte species (Maleki et al., 2018). Responses associated to salinity include differential tolerance at phenological stages, alterations at flowering stage, and changes in plant morphology, decreased productivity and in extreme cases, plant death. The response diversity is linked to genotypic variability, therefore must be included as target traits for breeding purposes (Fahad et al., 2015; Jarvis et al., 2017; Zou et al., 2017). Thus crop diversity throughout the Andean region and its expansion to different continents demands the requisite for research focusing at several levels and traits from management (i.e. fertilization, irrigation), physiological performance, abiotic and biotic stress tolerance, and grain yield. 
Table 2. Response of quinoa plants to edaphic salinity.

\begin{tabular}{|c|c|c|c|}
\hline Country & Cultivar & Response & Source \\
\hline Chile & R49 & $\begin{array}{l}\text { Reduction of chlorophyll contents, fresh and dried materials. } \\
\text { Increase of the } \mathrm{Na}^{+} \text {contents in leaves and roots }\end{array}$ & Ruiz et al. (2016) \\
\hline Australia & Pasankalla rosada & $\begin{array}{l}\text { Increase of } \mathrm{Na}^{+} \text {concentrations in plant tissues. } \\
\text { Marked reduction in stomatal density and increase in } \\
\text { chlorophyll fluorescence }\end{array}$ & Shabala et al. (2013) \\
\hline Iran & Titicaca & $\begin{array}{l}\text { High sensitivity in the vegetative stages, impact on growth } \\
\text { rates, grain production and germination percentage }\end{array}$ & Maleki et al. (2018) \\
\hline Colombia & Blanca Soracá & $\begin{array}{l}\text { Death of plants at the beginning of the vegetative stages } \\
\text { and changes in the early development of plants }\end{array}$ & $\begin{array}{l}\text { García-Parra et al. } \\
(2019 b)\end{array}$ \\
\hline
\end{tabular}

\section{Compositional characteristics of quinoa}

Plants continuously require energy for their growth and development. However, energy cannot be stored nor transported in ATP form, an issue that is alleviated mainly through the nocturnal oxidation of carbohydrates, allowing to obtain metabolic energy (ATP), in addition to $\mathrm{O}_{2}, \mathrm{CO}_{2}$ and water. As a result, environmental factors exert their influence on plant performance and particularly through the relationships of $\mathrm{CO}_{2}$ uptake and water and nutrient availability in the soil. These are the result of the triose phosphate production originating sugars, proteins and fatty acids which are transported from source to sinks organs (Neuhaus and Wagner, 2000; Raines, 2011).

In recent years, several quinoa reports demonstrated the effects of edaphoclimatic conditions in production and seed attributes. This indeed has strengthened quinoa production, favoring its ability to withstand climate change effects but also providing nutritional components over those of staple crops (Table 3). Current European countries that have been growing quinoa, are also studying agri-food potential of quinoa seed components. However, countries such as Argentina, Chile, Pakistan and India have also determined nutritional attributes of quinoa seeds. The productive and compositional characteristics of quinoa have reflected agroecological differences regarding altitude and latitude growth conditions (Table 4). At Colombian field assays, crop management practices modulated the grain proximal composition, i.e. fertilization effects highlighting organic sources. Also crop precocity differed by $22 \%$ between Peru and Spain for 'Salcedo'; expressing a 46\% higher yield in Peru compared to Chile. Interestingly, 'Sajama' in Argentina showed lowest protein content, which was interpreted by the authors as the effect of different natural conditions of crop growth site (from

Table 3. Nutritional values of cereals in relation to quinoa grains.

\begin{tabular}{lrrrrr}
\hline Component & Quinoa & Rice & Wheat & Corn & Barley \\
\hline Protein, \% & 14.1 & 8.1 & 7.2 & 9.9 & 9.9 \\
Total fat, \% & 6.0 & 2.2 & 1.5 & 4.8 & 1.1 \\
Carbohydrates, \% & 64.1 & 81.6 & 85.0 & 70.0 & 77.7 \\
Fiber, \% & 7.0 & 2.8 & 1.7 & 2.9 & 15.6 \\
Ash, \% & 2.7 & 0.1 & 0.5 & 1.3 & 0.6 \\
Energy, kcal & 368.0 & 370.0 & 339.0 & 394.0 & 352.0 \\
\hline
\end{tabular}

Adapted from Ullah et al. (2010); Fasahat et al. (2012); Shewry and Hey (2015); Mahender et al. (2016); Navruz-Varli and Sanlier (2016); USDA (2018); González et al. (2018a).

Table 4. Productive and compositional aspects of some quinoa cultivars and their relationship with the local conditions.

\begin{tabular}{llcrrl}
\hline Producer country (altitude) & \multicolumn{1}{c}{ Cultivar } & $\begin{array}{c}\text { Time to } \\
\text { maturity }\end{array}$ & Yield & $\begin{array}{c}\text { Protein } \\
\text { content }\end{array}$ & Source \\
\hline & & DAG & $\mathrm{kg} \mathrm{ha}^{-1}$ & $\%$ & \\
Chile (1462 m a.s.1.) & Salcedo & 180 & 2743.33 & 16.3 & Reguera et al. (2018) \\
Peru (2355 m a.s.l.) & & 145 & 5170.00 & 14.6 & \\
Spain (1399 m a.s.1.) & & 187 & - & 15.2 & \\
Bolivia (3960 m a.s.1.) & Sajama & & 2100.00 & 12.0 & Gonzalez et al. (2012) \\
Argentina (1995 m a.s.l.) & & & 1069.00 & 9.1 & \\
Colombia (2748 m a.s.l.) & Blanca Soracá T1 & 173 & 3800.00 & 14.3 & Garcia et al. (2018) \\
& Blanca Soracá T2 & 118 & 2900.00 & 15.6 & \\
Chile (Temuco 166 m a.s.1.) & Regalona & & 1800.00 & 18.1 & Aranda et al. (2013) \\
Chile (Vicuña 657 m a.s.l.) & & & 6000.00 & 19.0 & \\
\hline
\end{tabular}

T1: Organic fertilization; T2: mineral fertilization. DAG: days after germination. 
1995 to $3960 \mathrm{~m}$ a.s.l.), also affecting the grain yield. Meanwhile, evaluations comparing locations of Vicuña and Temuco in Chile (northern and southern, respectively) determined that 'Regalona' exceeded yields by $70 \%$ (Table 4).

\section{Importance of quinoa in Colombia}

Colombia's latitudes range between $11.5^{\circ} \mathrm{N}$ and $4.1^{\circ} \mathrm{S}$, with a wide biological, edaphic and climatic diversity, even though presence of Andes range influence contrasting altitude from 0 to $5400 \mathrm{~m}$ a.s.l. (Cataño-D. et al., 2014). The striking climatic differences of Colombian territory, not only challenge continuous food availability, but also the search for crops better adapted to climate disparities such as frost, unexpected temperature fluctuations as well as low water and nutrients availability. Although several researches suggested that Colombia is one of central countries of origin of $C$. quinoa, this species has not been such important part of modern agricultural production systems in the country, extension of this crop just reaches 2600 ha, and there are just few cultivars in use (i.e. Blanca de Jericó and Tunkahuan), along with a discrete participation (0.02\%) at international markets (Jäger, 2015; MADR, 2018).

Indeed, quinoa could play an important role in agricultural production systems, not only in the southwest Andean region including Nariño and Cauca departments, but also in Colombia central area, specifically Boyacá and Cundinamarca departments. Field trials carried out at these regions have shown successful development, productivity and precocity, not only in selected farmer's cultivars, but also in development breeding genotypes (Table 5). Despite its rusticity and superiority in nutritional and agro-industrial terms, quinoa in Colombia has been underutilized, and relationship between agroclimatic conditions and seed nutritional attributes has not been fully explored, inclusion of quinoa in School Feeding Plan (SFE) of Boyacá department benefits about 175000 children (Mineducación, 2015), while PANES program in Cauca department was initially associated to a strategy for substitution of illicit crops such as Papaver somniferum L. (Guerrero-López, 2018). Currently, it has become an alternative generating income for central and southern Colombian growers as well as, on a larger scale, access to abundant protein foods, surpassing traditional cereals such as corn and wheat in terms of nutritional qualities.

Table 5. Production and phenological cycle of some quinoa cultivars, data obtained in the central region of Colombia between 2000 and 2019.

\begin{tabular}{llcc}
\hline Cultivar & Origin & Yield & Productive cycle \\
\hline & & $\mathrm{kg} \mathrm{ha}^{-1}$ & Days after sowing \\
Cica 17 & Peru & 2.283 & $>200$ \\
Nariño & Colombia & $500-1000$ & $>200$ \\
Salcedo & Peru & $100-500$ & $160-180$ \\
Jujuy & Argentina & $>500$ & $160-180$ \\
Baer-II & Chile & $100-500$ & $150-170$ \\
RU-5 & England & $1600-1500$ & $140-150$ \\
NL-6 & Netherlands & $1100-1500$ & $140-150$ \\
Amarilla marangani & Peru & 2157 & $160-180$ \\
E-DK-4 & Denmark & 2808 & $140-150$ \\
G-205-95 & Denmark & 2083 & $140-150$ \\
Ingapirca & Ecuador & $600-1000$ & $180-200$ \\
02-Embrapa & Brazil & $100-500$ & $150-170$ \\
Piartal & Ecuador & - & 180 \\
Bolivia & Bolivia & - & 209 \\
Blanca Soraca & Colombia & 2430 & - \\
Blanca Jerico & Colombia & - & 150.7 \\
Tunkahuan & Ecuador & - & 161 \\
\hline
\end{tabular}

Source: Torres et al. (2000); Veloza-Ramírez et al. (2016); García-Parra et al. (2019a).

\section{CONCLUSIONS}

The increasing change of climatic conditions is expected to affect quinoa production in terms of physiological performance, i.e. precocity and crop productivity. However, given the capacity to tolerate adverse agroclimatic factors, quinoa is emerging in Colombia as a promising species to colonize marginal areas affected by restricted nutrient availability, low organic matter contents, temperature oscillations, water deficit and frost, mainly at Central highlands of Colombia. Also, it is a promising allele source regarding abiotic tolerance for breeding programs. 
Quinoa display higher photosynthetic efficiency at high $\mathrm{CO}_{2}$ contents with $\mathrm{C} 3$ pathway, conferring superior capacity to compete with $\mathrm{C} 4$ crop species or weeds. This also favors its metabolic processes, achieving high protein content seeds under environmentally marginal conditions. Outstanding nutritional quality and multiple potential uses in food industry are an imperative for a greater participation of research programs focusing in characterization cultivar diversity with enhanced adaptability to climate change, which concomitantly represents an opportunity for strengthening this species and its use in Colombian productive chain.

\section{ACKNOWLEDGEMENTS}

The authors express gratitude to Minciencias (Ministerio de Ciencia, Tecnología e Innovación) invitation for bid Nr. 779/2017. We are also grateful with the Boyacá Department Government, Cauca University and project CIUC-012018 carried out by the AOF-JDC.

\section{REFERENCES}

Abdelbar, OH. 2018. Flower vascularization and fruit developmental anatomy of quinoa (Chenpodium quinoa Willd) Amaranthaceae. Annals of Agricultural Sciences 63(1):67-75. https://doi.org/10.1016/j.aoas.2018.05.002.

Alvarez-Flores, R., Winkel, T., Nguyen-Thi-Truc, A., and Joffre, R. 2014. Root foraging capacity depends on root system architecture and ontogeny in seedlings of three Andean Chenopodium species. Plant and Soil 380(1):415-428. https://doi.org/10.1007/s11104-014-2105-x.

Aranda, M., López, J., Marín, R., Vega-Gálvez,A., Martínez, E.A., Fuentes, F., et al. 2013. Influence of contrasting environments on seed composition of two quinoa genotypes: nutritional and functional properties. Chilean Journal of Agricultural Research 73:108-116. https://doi.org/10.4067/s0718-58392013000200004.

Bascuñán-Godoy, L., Sanhueza, C., Hernández, C.E., Cifuentes, L., Pinto, K., Álvarez, R., et al. 2018a. Nitrogen supply affects photosynthesis and photoprotective attributes during drought-induced senescence in quinoa. Frontiers in Plant Science 9:994. https://doi.org/10.3389/fpls.2018.00994.

Bascuñán-Godoy, L., Sanhueza, C., Pinto, K., Cifuentes, L., Reguera, M., Briones, V., et al. 2018b. Nitrogen physiology of contrasting genotypes of Chenopodium quinoa Willd. (Amaranthaceae). Scientific Reports 8:112. https://doi.org/10.1038/s41598-018-34656-5.

Bazile, D., Bertero, D., y Nieto, C. 2014. Estado del arte de la quinua en el mundo en 2013. In Organización de las Naciones Unidas para la Alimentación y la Agricultura (FAO), Santiago, Chile, y Centre de Coopération Internationale en Recherche Agronomique pour le Développement (CIRAD), Montpellier, Francia.

Bazile, D., Jacobsen, S.-E., and Verniau, A. 2016. The global expansion of quinoa: Trends and limits. Frontiers in Plant Science 7:1-6. https://doi.org/10.3389/fpls.2016.00622.

Becker, V.I., Goessling, J.W., Duarte, B., Cacador, I., Liu, F., Rosenqvist, E., et al. 2017. Combined effects of soil salinity and high temperature on photosynthesis and growth of quinoa plants (Chenopodium quinoa). Functional Plant Biology 44(7):665. https://doi.org/10.1071/fp16370.

Bendevis, M.A., Sun, Y., Rosenqvist, E., Shabala, S., Liu, F., and Jacobsen, S.E. 2014. Photoperiodic effects on short-pulse ${ }^{14} \mathrm{C}$ assimilation and overall carbon and nitrogen allocation patterns in contrasting quinoa cultivars. Environmental and Experimental Botany 104:9-15. https://doi.org/10.1016/j.envexpbot.2014.03.002.

Bertero, D. 2001. Effects of photoperiod, temperature and radiation on the rate of leaf appearance in quinoa (Chenopodium quinoa Willd.) under field conditions. Annals of Botany 87(4):495-502. https://doi.org/10.1006/anbo.2000.1362.

Bertero, H. 2003. Response of developmental processes to temperature and photoperiod in quinoa (Chenopodium quinoa Willd.) Food Reviews International 19(1-2):87-97. https://doi.org/10.1081/fri-120018870.

Bertero, H.D., King, R.W., and Hall, A.J. 1999a. Modelling photoperiod and temperature responses of fowering in quinoa (Chenopodium quinoa Willd.). Field Crops Research 63(1):19-34. https://doi.org/10.1016/S0378-4290(99)00024-6.

Bertero, H.D., King, R.W., and Hall, A.J. 1999b. Photoperiod-sensitive development phases in quinoa (Chenopodium quinoa Willd.) Field Crops Research 60(3):231-243. https://doi.org/10.1016/S0378-4290(98)00128-2.

Bhargava, A., Shukla, S., and Ohri, D. 2006. Chenopodium quinoa - An Indian perspective. Industrial Crops and Products 23(1):73-87. https://doi.org/10.1016/j.indcrop.2005.04.002.

Bhargava, A., Shukla, S., and Ohri, D. 2007. Genetic variability and interrelationship among various morphological and quality traits in quinoa (Chenopodium quinoa Willd.) Field Crops Research 101(1):104116. https://doi.org/10.1016/j.fcr.2006.10.001.

Bois, J.F., Winkel, T., Lhomme, J.P., Raffaillac, J.P., and Rocheteau, A. 2006. Response of some Andean cultivars of quinoa (Chenopodium quinoa Willd.) to temperature: Effects on germination, phenology, growth and freezing. European Journal of Agronomy 25(1):299-308. https://doi.org/10.1016/j.eja.2006.06.007. 
Bosque Sanchez, H., Lemeur, R., Van Damme, P., and Jacobsen, S.E. 2003. Ecophysiological analysis of drought and salinity stress of quinoa (Chenopodium quinoa Willd.) Food Reviews International 19(1-2):111-119. https://doi.org/10.1081/FRI-120018874.

Bunce, J. 2017. Variation in yield responses to elevated $\mathrm{CO}_{2}$ and a brief high temperature treatment in quinoa. Plants 6(4):26. https://doi.org/10.3390/plants6030026.

Cataño-D., E., Uribe-M., J., y Campos, L.V. 2014. Diversidad de hepáticas y musgos en turberas del nevado del Tolima, Colombia. Caldasia 36(2):217-229. http://dx.doi.org/10.15446/caldasia/v36n2.47479.

Christiansen, J.L., Jacobsen, S.E., and Jorgensen, S.T. 2010. Photoperiodic effect on flowering and seed development in quinoa (Chenopodium quinoa Willd.) Acta Agriculturae Scandinavica Section B: Soil and Plant Science 60(6):539-544. https://doi.org/10.1080/09064710903295184.

Del Castillo, C., Mahy, G., et Winkel, T. 2008. La quinoa en Bolivie: Une culture ancestrale devenue culture de rente "bioéquitable." Biotechnology, Agronomy and Society and Environment 12(4):445-454.

Delgado, A., Palacios, J., y Betancourt, C. 2009. Evaluación de 16 genotipos de quinua dulce (Chenopodium quinoa Willd.) en el municipio de Iles, Nariño (Colombia). Agronomía Colombiana 27(2):159-167.

Eisa, S., Hussin, S., Geissler, N., and Koyro, H.W. 2012. Effect of $\mathrm{NaCl}$ salinity on water relations, photosynthesis and chemical composition of quinoa (Chenopodium quinoa Willd.) as a potential cash crop halophyte. Australian Journal of Crop Science 6(2):357-368. https://doi.org/10.1111/j.1399-3054.2012.01599.x.

Fahad, S., Hussain, S., Matloob, A., Khan, F.A., Khaliq, A., Saud, S., et al. 2015. Phytohormones and plant responses to salinity stress: A review. Plant Growth Regulation 75(2):391-404. https://doi.org/10.1007/s10725-014-0013-y.

FAO-ALADI. 2014. Tendencias y perpectivas del comercio internacional de la quinua. Organización de las Naciones Unidas para la Alimentación y la Agricultura (FAO)-Asociación Latinoamericana de Integración (ALADI), Santiago, Chile.

Fasahat, P., Muhammad, K., Abdullah, A., and Ratnam, W. 2012. Proximate nutritional composition and antioxidant properties of Oryza rufipogon, a wild rice collected from Malaysia compared to cultivated rice, MR219. Australian Journal of Crop Science 6(11):1502-1507.

Fischer, G., Ramírez, F., and Casierra-Posada, F. 2016. Ecophysiological aspects of fruit crops in the era of climate change. A review. Agronomía Colombiana 34(2):190-199. https://doi.org/10.15446/agron.colomb.v34n2.56799.

García, M.A., García, J., Melo, D., y Deaquiz, Y. 2017. Respuesta agronómica de la quinua (Chenopodium quinoa Willd) variedad dulce de soracá a la fertilización en Ventaquemada-Boyacá. Cultura Científica 15:66-77.

García, M.A., y Plazas, N. 2018. La quinua (Chenopodium quinoa Willd) en los sistemas de producción agraria. Revista Producción + Limpia 13(1):112-119. https://doi.org/10.22507/pml.v13n1a6.

García-Parra, M.A., García-Molano, J., and Deaquiz-Oyola, Y.2019a. Physiological performance of quinoa (Chenopodium quinoa Willd.) under agricultural climatic conditions in Boyaca, Colombia. Agronomía Colombiana 37(2):160-168. https://doi.org/10.15446/agron.colomb.v37n2.76219.

García-Parra, M.A., García-Molano, J.F., y Quito, C. 2019b. Efecto de la salinidad por NaCl en el crecimiento y desarrollo de plantas de Chenopodium quinoa Willd. Ciencia en Desarrollo 10(1). https://doi.org/10.19053/01217488.v10.n1.2019.8341.

García-Parra, M.A., y Plazas-Leguizamón, N.Z. 2019. Análisis del ciclo de vida de las publicaciones sobre la producción de quinua (Chenopodium quinoa Willd), a través de curvas en S. Revista de Investigación, Desarrollo e Innovación 9(2):379391. https://doi.org/10.19053/20278306.v9.n2.2019.9189.

Garcia-Parra, M., García-Molano, J.F., y Carvajal, D.C. 2018. Evaluación del efecto de la fertilización química y orgánica en la composición bromatológica de semillas de quinua (Chenopodium quinoa Willd) en Boyacá-Colombia. Revista de Investigación Agraria y Ambiental 9(2):99-108. https://doi.org/10.22490/21456453.2282.

Geissler, N., Hussin, S., El-Far, M.M., and Koyro, H.W. 2015. Elevated atmospheric $\mathrm{CO}_{2}$ concentration leads to different salt resistance mechanisms in a $\mathrm{C}_{3}$ (Chenopodium quinoa) and a $\mathrm{C}_{4}$ (Atriplex nummularia) halophyte. Environmental and Experimental Botany 118:67-77. https://doi.org/10.1016/j.envexpbot.2015.06.003.

Geren, H. 2015. Effects of different nitrogen levels on the grain yield and some yield components of quinoa (Chenopodium quinoa Willd.) under Mediterranean climatic conditions. Turkish Journal of Field Crops 20(1):59-64. https://doi.org/10.17557/.39586.

Gómez, L., y Aguilar, E. 2016. Guía del cultivo de la quinua. FAO y Universidad Nacional Agraria La Molina, Lima, Perú.

González, J.A., Bruno, M., Valoy, M., and Prado, F.E. 2011. Genotypic variation of gas exchange parameters and leaf stable carbon and nitrogen isotopes in ten quinoa cultivars grown under drought. Journal of Agronomy and Crop Science 197(2):8193. https://doi.org/10.1111/j.1439-037X.2010.00446.x.

González, J.A., Erazzú, L.E., Buedo, S.E., y Prado, F.E. 2018b. Efecto de la densidad de siembra sobre la actividad fotosintética en Chenopodium quinoa var. CICA (“quínoa”) en el Norte Argentino. Boletín de la Sociedad Argentina de Botánica 53(1):21-29.

González, J.A., Konishi, Y., Bruno, M., Valoy, M., and Prado, F.E. 2012. Interrelationships among seed yield, total protein and amino acid composition of ten quinoa (Chenopodium quinoa) cultivars from two different agroecological regions. Journal of the Science of Food and Agriculture 92(6):1222-1229. https://doi.org/10.1002/jsfa.4686.

González, I.G., Tarón, A., and García-Zapateiro, L.A. 2018a. Physical, chemical and biological properties of maize variety Fr28. Contemporary Engineering Sciences 11(6):257-268. https://doi.org/10.12988/ces.2018.8114. 
Guerrero-López, A. 2018. Impacto del cultivo de la quinua (Chenopodium quinoa Willd) como alternativa productiva y socioeconómica en la comunidad indígena Yanacona de La Vega, Cauca, Colombia. 133 p. Tesis de Doctorado en Agroecología, Universidad Nacional de Colombia, Bogotá, Colombia.

Hariadi, Y., Marandon, K., Tian, Y., Jacobsen, S.E., and Shabala, S. 2011. Ionic and osmotic relations in quinoa (Chenopodium quinoa Willd.) plants grown at various salinity levels. Journal of Experimental Botany 62(1):185-193. https://doi.org/10.1093/jxb/erq257.

Hinojosa, L., González, J., Barrios-Masias, F., Fuentes, F., and Murphy, K. 2018. Quinoa abiotic stress responses: A review. Plants 7(4):106. https://doi.org/10.3390/plants7040106.

Huarancca Reyes, T., Scartazza, A., Castagna, A., Cosio, E.G., Ranieri, A., and Guglielminetti, L. 2018. Physiological effects of short acute UVB treatments in Chenopodium quinoa Willd. Scientific Reports 8(1):1-12. https://doi.org/10.1038/s41598-017-18710-2.

Jacobsen, S. 2017. The scope for adaptation of quinoa in Northern Latitudes of Europe. Journal of Agronomy and Crop Science 203(6):603-613. https://doi.org/10.1111/jac.12228.

Jacobsen, S.E., and Bach, A. 1998. The influence of temperature on seed germination rate in quinoa (Chenopodium quinoa Willd.) Seed Science and Technology 26:515-523.

Jacobsen, S.E., Monteros, C., Christiansen, J.L., Bravo, L.A., Corcuera, L.J., and Mujica, A. 2005. Plant responses of quinoa (Chenopodium quinoa Willd.) to frost at various phenological stages. European Journal of Agronomy 22(2):131-139. https://doi.org/10.1016/j.eja.2004.01.003.

Jäger, M. 2015. El cultivo de la quinua en Colombia y sus perspectivas futuras. Memorias del Taller, Cali, Colombia. 26 y 27 de agosto 2015. Centro Internacional de Agricultura Tropical (CIAT); Corporación Colombiana de Investigación Agropecuaria (CORPOICA), Cali, Colombia.

Jaikishun, S., Li, W., Yang., Z., and Song, S. 2019. Quinoa: In perspective of global challenges. Agronomy 9(4):176. https://doi.org/10.3390/agronomy9040176

Jarma, A., Cardona, C., and Araméndiz, H. 2012. Effect of climate change on the physiology of crop plants: A review. Revista U.D.C.A. Actualidad \& Divulgación Científica 15(1):63-76.

Jarvis, D., Ho, Y., Lightfoot, D., Schmöckel, S., Li, B., Borm, T., et al. 2017. The genome of Chenopodium quinoa. Nature 542(7641):307-312. https://doi.org/10.1038/nature21370.

Korres, N.E., Norsworthy, J.K., Tehranchian, P., Gitsopoulos, T.K., Loka, D.A., Oosterhuis, D.M., et al. 2016. Cultivars to face climate change effects on crops and weeds: A review. Agronomy for Sustainable Development 36:12. https://doi.org/10.1007/s13593-016-0350-5.

Kosanic, A., Anderson, K., Harrison, S., Turkington, T., and Bennie, J. 2018. Changes in the geographical distribution of plant species and climatic variables on the West Cornwall peninsula (South West UK). PLOS ONE 13(2):1-18. https://doi.org/10.1371/journal.pone.0191021.

Lesjak, J., and Calderini, D.F. 2017. Increased night temperature negatively affects grain yield, biomass and grain number in Chilean quinoa. Frontiers in Plant Science 8(352):1-11. https://doi.org/10.3389/fpls.2017.00352.

MADR. 2016. La quinua en Colombia es uno de los cultivos con gran potencial de crecimiento. Ministerio de Agricultura y Desarrollo Rural (MADR) de Colombia, Bogotá, Colombia. Available at https://www.minagricultura.gov.co/noticias/ Paginas/La-quinua-en-Colombia-es-uno-de-los-cultivos-con-gran-potencial-de-crecimiento.aspx (accessed 6 June 2019).

MADR. 2018. En los últimos 4 años, la quinua ha tenido un crecimiento de más del $150 \%$ en áreas de producción. Ministerio de Agricultira y Desarrollo Rural (MADR) de Colombia, Bogotá, Colombia. Available at https://www.minagricultura.gov. co/noticias/Paginas/En-los-últimos-4-años,-la-quinua-ha-tenido-un-crecimiento-de-más-del-150-en-áreas-de-producción- . aspx (accessed 13 February 2019).

Mahender, A., Anandan, A., Pradhan, S.K., and Pandit, E. 2016. Rice grain nutritional traits and their enhancement using relevant genes and QTLs through advanced approaches. SpringerPlus 5(1):1-18. https://doi.org/10.1186/s40064-016-3744-6.

Maleki, P., Bahrami, H.A., Saadat, S., Sharifi, F., Dehghany, F., and Salehi, M. 2018. Salinity threshold value of Quinoa (Chenopodium quinoa Willd.) at various growth stages and the appropriate irrigation method by saline water. Communications in Soil Science and Plant Analysis 49(15):1815-1825. https://doi.org/10.1080/00103624.2018.1474917.

Mamedi,A., Tavakkol,R., and Oveisi, M. 2017. Cardinal temperatures for seed germination of three quinoa (Chenopodium quinoa Willd.) cultivars. Iranian Journal of Field Crop Science 1(1):89-100. https://doi.org/10.22059/ijfcs.2017.206204.654106.

Marengo, J., Boulanger, M., Buckeridge, M., Castellanos, E., Poveda, G., Scarano, F., et al. 2014. Central and South America. p. 1499-1566. In Climate change 2014: Impacts, adaptation, and vulnerability. Cambrige University Press, Cambridge, UK.

Melo, D. 2016. Studio di adattabilità colturale della quinoa (Chenopodium quinoa willd.) in Italia settentrionale. 140 p. PhD thesis. Università Cattolica del Sacro Cuore, Piacenza, Italia.

Mineducación. 2015. Lineamiento técnico administrativo del PAE. Ministerio de Educación, Bogotá, Colombia.

Montes-Rojas, C., Guido-Catuche, B., Muñoz-Certuche, E., y Calderón-Yonda, Y. 2018. Descripción del ciclo fenológico de cuatro ecotipos de (Chenopodium quinua Willd.), en Puracé-Cauca, Colombia. Biotecnología en el Sector Agropecuario y Agroindustrial 16(2):26-37. https://doi.org/http://dx.doi.org/10.18684/bsaa.v16n2.97.

Morales, A., Zurita-Silva, A., Maldonado, J., and Silva, H. 2017. Transcriptional responses of Chilean quinoa (Chenopodium quinoa Willd.) under water deficit conditions uncovers ABA-independent expression patterns. Frontiers in Plant Science 8:56-13. http://doi.org/10.3389/fpls.2017.00216. 
Murphy, K., and Matanguihan, J. 2015. Quinoa improvement and sustainable production. John Wiley and Sons, Hoboken, New Jersey, USA.

Navruz-Varli, S., and Sanlier, N. 2016. Nutritional and health benefits of quinoa (Chenopodium quinoa Willd.) Journal of Cereal Science 69:371-376. https://doi.org/10.1016/j.jcs.2016.05.004.

Neuhaus, H., and Wagner, R. 2000. Solute pores, ion channels, and metabolite transporters in the outer and inner envelope membranes of higher plant plastids. Biochimica et Biophysica Acta - Biomembranes 1465(1-2):307-323. https://doi. org/10.1016/S0005-2736(00)00146-2.

Olvera, H.F., Smets, E., and Vrijdaghs, A. 2008. Floral and inflorescence morphology and ontogeny in Beta vulgaris, with special emphasis on the ovary position. Annals of Botany 102(4):643-651. https://doi.org/10.1093/aob/mcn140.

Präger, A., Munz, S., Nkebiwe, P., Mast, B., and Graeff-Hönninger, S. 2018. Yield and quality characteristics of different quinoa (Chenopodium quinoa Willd.) cultivars grown under field conditions in Southestern Germany. Agronomy 8(10):197. https://doi.org/ 10.3390/agronomy8100197.

Raines, C.A. 2011. Increasing photosynthetic carbon assimilation in $\mathrm{C}_{3}$ plants to improve crop yield: Current and future strategies. Plant Physiology 155(1):36-42. https://doi.org/10.1104/pp.110.168559.

Reguera, M., Conesa, C., Gil-Gómez, A., Haros, C., Pérez-Casas, M., Briones-Labarca, V., et al. 2018. The impact of different agroecological conditions on the nutritional composition of quinoa seeds. PeerJ 14(6):1-20. https://doi.org/10.7717/peerj.4442.

Ruiz, K., Aloisi, I., Del Duca, S., Canelo, V., Torrigiani, P., Silva, H., et al. 2016. Salares versus coastal ecotypes of quinoa: Salinity responses in Chilean landraces from contrasting habitats. Plant Physiology and Biochemistry 101:113. https://doi.org/10.1016/j.plaphy.2016.01.010.

Ruiz, K.B., Biondi, S., Oses, R., Acuña-Rodríguez, I.S., Antognoni, F., Martinez-Mosqueira, E.A., et al. 2014. Quinoa biodiversity and sustainability for food security under climate change. A review. Agronomy for Sustainable Development 34(2):349-359. https://doi.org/10.1007/s13593-013-0195-0.

Sanabria, K.M., y Lazo, H.O. 2018. Aclimatación a la alta temperatura y tolerancia al calor (TL 50) en 6 variedades de Chenopodium quinoa. Revista Peruana de Biología 25:147-152.

Shabala, S., Hariadi, Y., and Jacobsen, S.E. 2013. Genotypic difference in salinity tolerance in quinoa is determined by differential control of xylem $\mathrm{Na}^{+}$loading and stomatal density. Journal of Plant Physiology 170(10):906914. https://doi.org/10.1016/j.jplph.2013.01.014.

Shewry, P.R., and Hey, S.J. 2015. The contribution of wheat to human diet and health. Food and Energy Security 4(3):178-202. https://doi.org/10.1002/FES3.64.

Singh, D. 2019. Quinoa (Chenopodium quinoa Willd): A potential crop for future food, health security, livelihood generation and poverty eradication. Scientific Publishers, Jodhpur, India.

Taiz, L., y Zeiger, E. 2006. Fisiología vegetal. Universitat Jaume I, Castelló de la Plana, España.

Torres, J., Vargas, H., Corredor, G., y Luz, R.M. 2000. Caracterización morfoagronómica de diecinueve cultivares de quinua (Chenopodium quinoa Willd.) en la sabana de Bogotá. Agronomía Colombiana 17:60-68.

Tsutsumi, N., Tohya, M., Nakashima, T., and Ueno, O. 2017. Variations in structural, biochemical, and physiological traits of photosynthesis and resource use efficiency in Amaranthus species (NAD-ME-type $\mathrm{C}_{4}$ ). Plant Production Science 20(3):300312. https://doi.org/10.1080/1343943X.2017.1320948.

Ullah, I., Ali, M., and Farooqi, A. 2010. Chemical and nutritional properties of some maize (Zea mays L.) varieties grown in NWFP, Pakistan. Pakistan Journal of Nutrition 9(11):1113-1117. https://doi.org/10.3923/pjn.2010.1113.1117.

USDA. 2018. Basic report 20005. Barley raw: Nutrients values and weight are for edible portion. USA. Available at https://ndb. nal.usda.gov/ndb/foods/show $/ 20005$ fgcd=ymanu=\&format=\&count $=\&$ max $=25 \&$ offset=\&sort=default \&order $=$ asc $\& q l o o k$ up $=$ barley $\& \mathrm{ds}=\& \mathrm{qt}=\& \mathrm{qp}=\& \mathrm{qa}=\& \mathrm{qn}=\& \mathrm{q}=\&$ ing $=$.

Veloza-Ramírez, C., Romero-Guerrero, G., y Gómez-Piedras, J.J. 2016. Respuesta morfoagronómica y calidad en proteína de tres accesiones de quinua (Chenopodium quinoa Willd.) en la sabana norte de Bogotá. Revista UDCA Actualidad y Divulgación Científica 19(2):325-332. https://doi.org/10.31910/rudca.v19.n2.2016.86.

Villalobos-Rodríguez, E. 2001. Fisiología de la producción de los cultivos tropicales (I). Editorial Universidad de Costa Rica, San José, Costa Rica.

Yang, A., Akhtar, S.S., Amjad, M., Iqbal, S., and Jacobsen, S.E. 2016. Growth and physiological responses of quinoa to drought and temperature stress. Journal of Agronomy and Crop Science 202(6):445-453. https://doi.org/10.1111/jac.12167.

Zou, C., Chen, A., Xiao, L., Muller, H.M., Ache, P., Haberer, G., et al. 2017. A high-quality genome assembly of quinoa provides insights into the molecular basis of salt bladder-based salinity tolerance and the exceptional nutritional value. Cell Research 27(11):1327-1340. https://doi.org/10.1038/cr.2017.124.

Zurita-Silva, A., Fuentes, F., Zamora, P., Jacobsen, S.-E., and Schwember, A.R. 2014. Breeding quinoa (Chenopodium quinoa Willd.): potential and perspectives. Molecular Breeding 34(1):13-30. http://doi.org/10.1007/s11032-014-0023-5. 